\title{
NATURAL RADIOACTIVITY LEVELS AND ESTIMATION OF RADIATION EXPOSURE IN AGRICULTURAL SOILS FROM SKOPJE CITY REGION
}

\author{
Aleksandra Angjeleska1 ${ }^{1}$, Elizabeta Dimitrieska-Stojkovicic1,", Zehra Hajrulai-Musliu1, \\ Radmila Črčeva-Nikolovska ${ }^{1}$, Boško Boškovski ${ }^{2}$ \\ ${ }^{1}$ Ss Cyril and Methodius University, Faculty of Veterinary Medicine, Food Institute, \\ Lazar Pop-Trajkov 5-7, 1000 Skopje, Republic of Macedonia \\ ${ }^{2}$ Ss Cyril and Methodius University, Faculty of Technology and Metallurgy in Skopje, \\ Ruger Bošković 16, Skopje, Republic of Macedonia \\ edimitrieska@fvm.ukim.edu.mk
}

\begin{abstract}
The aim of this study was to determine the activity concentrations of naturally occurring radioisotopes ${ }^{226} \mathrm{Ra},{ }^{232} \mathrm{Th}$ and ${ }^{40} \mathrm{~K}$ in 14 soil samples collected in the Skopje city surroundings, and to calculate the corresponding absorbed gamma dose rates. The radionuclides were measured applying a high purity Ge detector gamma-ray spectrometer with relative efficiency of $30 \%$ at $1.33 \mathrm{MeV}$. The activity concentrations found in 14 soil samples varied in the range of $24.1-41.9 \mathrm{~Bq} \mathrm{~kg}^{-1}$ for ${ }^{226} \mathrm{Ra}, 38.5-52.2 \mathrm{~Bq} \mathrm{~kg}^{-1}$ for ${ }^{232} \mathrm{Th}$ and $502-707 \mathrm{~Bq} \mathrm{~kg}^{-1}$ for ${ }^{40} \mathrm{~K}$. The mean radium equivalent $\left(\mathrm{Ra}_{\mathrm{eq}}\right)$, for the area under investigation, was $143 \pm 16 \mathrm{~Bq} \mathrm{~kg}^{-1}$, while the outdoor radiation hazard index $\left(H_{\mathrm{ex}}\right)$ was 0.39 . The total absorbed dose rate due to the three primordial radionuclides investigated lay in the range of 55.3-79.0 $\mathrm{nGy} \mathrm{h}^{-1}$ with a mean value of $68.1 \pm 7.7 \mathrm{nGy} \mathrm{h}^{-1}$, yielding a total annual effective dose of $(83.5 \pm 9.5) \mu \mathrm{Sv} \mathrm{y}^{-1}$. The assessed radiological factors were lower than the recommended values, indicating a low radiological health risk for the population living and working in the investigated area. The activity concentrations of radionuclides in soil samples were compared to the international values reported by United Nations Scientific Committee on the Effects of Atomic Radiation and previous studies on geographically close areas and some worldwide regions.
\end{abstract}

Keywords: natural radioactivity; soil; gamma spectrometry; activity concentrations; radiological risks

\section{НИВОА НА ПРИРОДНАТА РАДИОАКТИВНОСТ И ПРОЦЕНА НА ИЗЛОЖЕНОСТ НА РАДИЈАЦИЈА ОД ЗЕМЈОДЕЛСКОТО ЗЕМЈИШТЕ ВО РЕГИОНОТ НА ГРАДОТ СКОПЈЕ}

Целта на ова истражување беше да се определат концентрациите на активноста на природно присутните радионуклиди ${ }^{226} \mathrm{Ra},{ }^{232} \mathrm{Th}$ и ${ }^{40} \mathrm{~K}$ во 14 примероци почва од околината на градот Скопје, како и пресметка на соодветните апсорбирани дози. Радионуклидите беа измерени со примена на гама-спектрометар со германиумски детектор со висока чистота, со релативна ефикасност од $30 \%$ на 1,33 MeV. Концентрациите на активност беа определени во 14 примероци почва и се движеа во опсегот од 24.1 до $41.9 \mathrm{~Bq} \mathrm{~kg}^{-1}$ за ${ }^{226} \mathrm{Ra}$, од 38.5 до $52.2 \mathrm{~Bq} \mathrm{~kg}^{-1}$ за ${ }^{232} \mathrm{Th}$ и од 502 до $707 \mathrm{~Bq} \mathrm{~kg}^{-1}$ за ${ }^{40} \mathrm{~K}$. Просечната вредност за радиумскиот еквивалент $\left(\mathrm{Ra}_{\mathrm{eq}}\right)$ во истражуваната област беше $143 \pm$ $16 \mathrm{~Bq} \mathrm{~kg}{ }^{-1}$, додека пак вредноста на индексот на радијациона опасност $\left(H_{\mathrm{ex}}\right)$ за отворена средина беше 0,39. Вкупната апсорбирана доза која потекнува од истражените три приморадијални радионуклиди се движеше во опсегот од 55.3 до $79.0 \mathrm{nGy} \mathrm{h}^{-1}$, со просечна вредност од $68.1 \pm 7.7$ $\mathrm{nGy} \mathrm{h}^{-1}$, која учествува во вкупната годишна ефективна доза со $83.5 \pm 9.5 \mu \mathrm{Sv} \mathrm{y}^{-1}$. Проценетите радиолошки фактори беа пониски од препорачаните вредности, што укажува на низок радиолошки ризик по здравјето на населението кое живее и работи во истражуваното подрачје. Определените концентрации на активноста беа споредени со објавените вредности на меѓународно ниво од страна на Научниот комитет на Обединетите Нации за ефектите од атомското зрачење, како и со претходно спроведените истражувања за географски блиски региони и некои региони низ светот. 
Клучни зборови: природна радиоактивност; почва; гама спектрометрија;

концентрации на активност; радиолошки ризици

\section{INTRODUCTION}

Human beings have always been exposed to radiation, arising from different sources such as cosmic rays, natural radioactivity of the environment and plants, and artificially generated radioactivity from fallout, nuclear activities, and medical applications [1]. The soil is a first element in the environmental chain soil-food-humans; therefore, it plays a significant role in the radionuclide transfer and distribution. There are around 40 natural radioactive substances in the soil, with various contributions, but predominantly, the natural environmental radioactivity mainly arises from three primordial radionuclides such as ${ }^{40} \mathrm{~K}$, and the nuclides from the ${ }^{238} \mathrm{U}$ and ${ }^{232} \mathrm{Th}$ decay series $[2,3]$. These radionuclides are from the nucleo-synthesis process in the stars and are characterized by halflives comparable to the Earth's age [3].

Once present in the environment, these radioisotopes are available for uptake by the plants and animals, thus entering in the food chain. Therefore, the information on the soil radio-contamination is a basis for further establishment of criteria and norms for radiation safety. Natural soil radioactivity and the associated exposure due to gamma radiation are primarily dependent on the geological and geographical properties, even though at different levels, they appear in the soils throughout the whole world [4-6]. The assessment of gamma radiation doses originating from natural sources is of particular significance, as natural radiation predominantly, via soil, water, local vegetation, and the air of a region, contributes to the external dose of the population within a specific region [1]. Furthermore, this data is a valuable input in forming the basis for evaluation of the degree of the possible future radioactive pollution [7]. The growing worldwide interest in natural radioactivity has resulted in extensive surveys in many countries [3, 8-16]. External gamma dose estimation from the terrestrial sources is essential because not only does it present a considerable contribution to the collective dose, estimated at $0.46 \mathrm{mS} \mathrm{y}^{-1}$, but also is important for the implementation of precautionary measures whenever the findings reveal doses above the recommended limits $[1,11]$. These doses are variable depending upon the concentrations of the natural radionuclides, ${ }^{238} \mathrm{U},{ }^{232} \mathrm{Th}$, and their decay series, and ${ }^{40} \mathrm{~K}$, present in soils and rocks [11]. The average abundance in the upper Earth crust of potassium, uranium and thorium is $2.7 \%, 2.5 \mathrm{ppm}$, and $10.5 \mathrm{ppm}$, respectively. As an alkali metal with an ionic radius of $0.16 \mathrm{~nm}$, potassium is one of the so-called large ion lithophile elements and tends to be depleted in evolved crustal rocks. Uranium with an ionic radius of $0.1 \mathrm{~nm}$ and thorium with an ionic radius of $0.11 \mathrm{~nm}$ are also considered as large lithophile elements. However, their lower abundances mean that minerals that contain uranium and thorium as essential constituents are present as trace minerals in common rocks. The natural radioactivity is usually determined measuring the activities of ${ }^{226} \mathrm{Ra},{ }^{232} \mathrm{Th}$ and ${ }^{40} \mathrm{~K}$. It is considered that radium and its decay products cause $98.5 \%$ of the radiological effects of the uranium series [11].

Republic of Macedonia is located in the central part of the Balkan Peninsula with an area of 25 $713 \mathrm{~km}^{2}$ [17]. The average altitude is $832 \mathrm{~m}$, with a north latitude between $40^{\circ} 50^{\prime}$ and $42^{\circ} 20^{\prime}$, and an east longitude between $20^{\circ} 27^{\prime} 30^{\prime \prime}$ and $23^{\circ} 05^{\prime}$ [17]. The vicinity of the city of Skopje is located in the northern part of the state, spread over the Skopje Valley in a northwest southeast direction, being 47 $\mathrm{km}$ long. The studied area is surrounded by hills from the north, west and south. The total area is $2100 \mathrm{~km}^{2}$ with an altitude between 173 and $340 \mathrm{~m}$, at $41^{\circ} 53^{\prime} 42^{\prime \prime}$ north latitude and $21^{\circ} 18^{\prime} 30^{\prime \prime}$ east longitude. The average annual air temperature in 2012 was $13.7^{\circ} \mathrm{C}$, with average annual rainfalls of 412.7 $\mathrm{mm}$ [17]. The city of Skopje, besides being the capital of Macedonia, is known for its steel, cement, and pharmaceutical production industries. The surrounding area is predominantly agricultural with a variety of cultures grown on it, mainly crops and vegetables.

So far, there has been only limited data on natural radioactivity in raw products for building materials applied in Republic of Macedonia [18], as well as the vertical distribution of natural radionuclides ${ }^{226} \mathrm{Ra},{ }^{232} \mathrm{Th},{ }^{40} \mathrm{~K}$ [19] and the natural radioactivity in non-cultivated soils [20]. However, regarding the assessment of doses occurring from the natural radioactivity and absorbed by the population from the Republic of Macedonia, there is data available for other investigated regions [21, 22].

The objective of our study was focused on determining the natural radioactivity levels in collected soil samples from 14 locations in the surroundings of the capital city of Skopje, Republic of Macedonia, where the highest population density $\left(370 \mathrm{~km}^{-2}\right)$ is present [17]. For this purpose, the ac- 
tivity concentrations of ${ }^{226} \mathrm{Ra},{ }^{232} \mathrm{Th}$ and ${ }^{40} \mathrm{~K}$, were determined by applying gamma spectroscopy. Furthermore, from the natural radioactivity data obtained, the radiation hazard indices and the effective dose to the population occupationally engaged in this area, will be evaluated. The performed statistical analysis, such as the Pearson correlation, provided knowledge for the linear relationship between the activity concentrations of the three radionuclides of interest in this study $\left({ }^{226} \mathrm{Ra},{ }^{232} \mathrm{Th}\right.$ and $\left.{ }^{40} \mathrm{~K}\right)$, as well as between the radiological parameters arising from them in the investigated soil samples.

\section{EXPERIMENTAL}

\subsection{Sampling}

Fourteen soil samples were collected from the locations in the surroundings of the city of Skopje (Fig. 1), during 2012. The sampling was performed at three soil depths: $0-5 \mathrm{~cm}, 5-10 \mathrm{~cm}$, and $10-15 \mathrm{~cm}$, employing a suitable sampling de- vice with $700 \mathrm{~mm}$ length, enabling sampling only at the desired depths. According to International Atomic Energy Agency (IAEA) recommendations [23], sampling was performed in duplicate. Thus, in total, from every location, six soil samples were collected. During the sampling, special care was taken about the micro-location flatness, excluding the consequences of possible horizontal radionuclide translocation.

After removing the stones and organic impurities, the samples were dried in an oven at $110^{\circ} \mathrm{C}$ for 24 hours, to remove the moisture. Then, the samples were crushed and passed through $150 \mu \mathrm{m}$ sieve. The homogenized samples were weighed, and a mass from 480 to $490 \mathrm{~g}$ of each sample was packed in polyethylene Marinelli beakers with an active volume of $480 \mathrm{~cm}^{3}$. After tightening, the containers were sealed with adhesive tape and left for 21 day before measuring with gamma spectrometry. This was in order to ensure that the daughter products of ${ }^{226} \mathrm{Ra}$ and ${ }^{228} \mathrm{Th}$ had achieved equilibrium with the respective parent radionuclides [11].

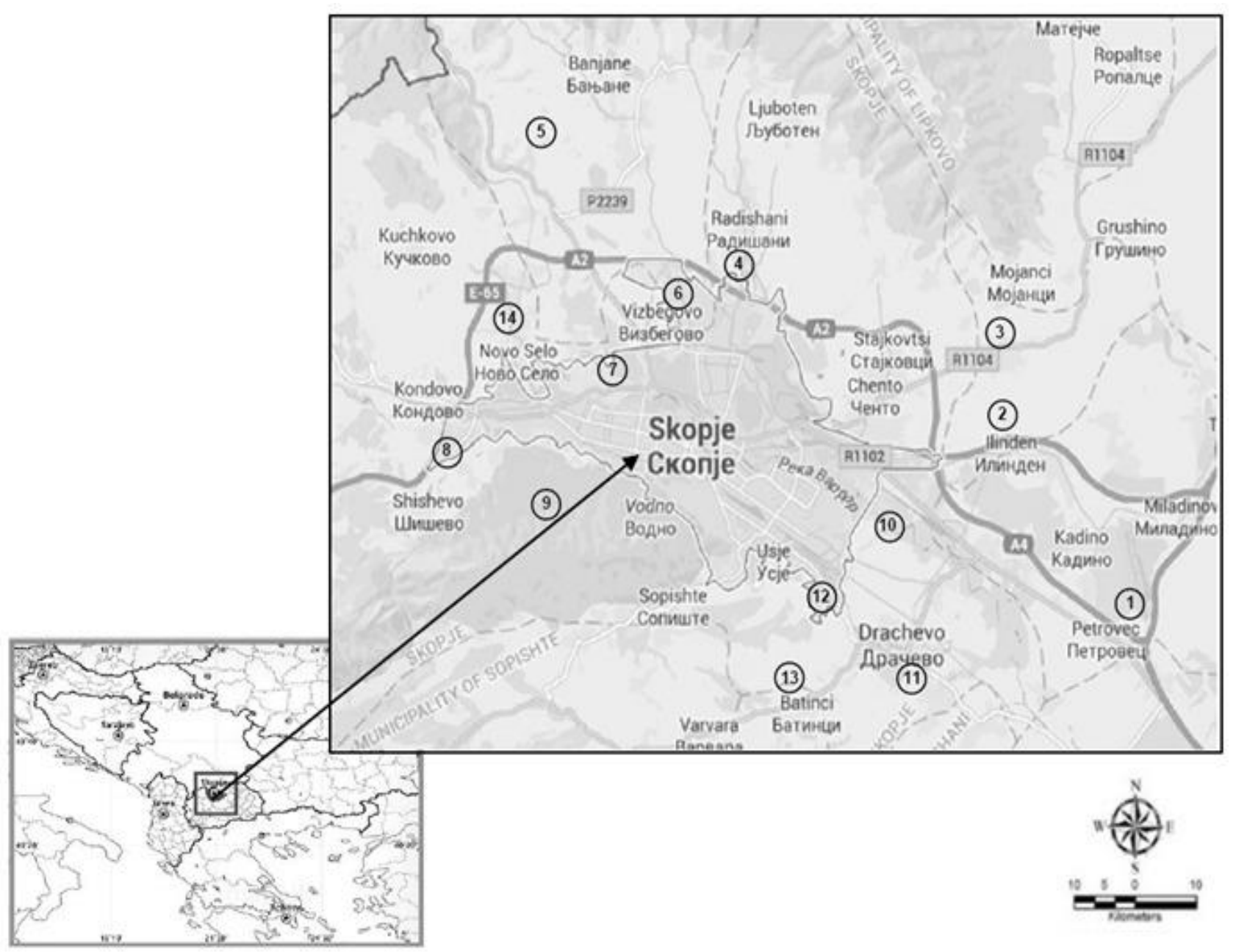

Fig. 1. Sampling locations for samples from the surroundings of the city of Skopje 


\subsection{Gamma spectrometry measurements}

The gamma ray spectrometry technique was used for radioactivity determination of the samples tested. The spectrometer consisted of a high purity (HP) Ge detector, model 3020 (Canberra Packard, Meriden, CT, USA), with relative efficiency of 30 $\%$ at $1.33 \mathrm{MeV}$. The detector was enclosed in massive $12 \mathrm{~cm}$ thick lead shielding and an internal lining of $2 \mathrm{~mm}$ high purity copper. Data acquisition and analysis were performed with an 8192 channel digital analyzer; the duration of acquisition interval for each sample was $65 \mathrm{ks}$. The activity of ${ }^{226} \mathrm{Ra}$ was determined from the gamma lines associated with low half-life time daughters of ${ }^{214} \mathrm{Bi}(609.31$, 1120.29 and $1794.49 \mathrm{keV})$ and ${ }^{214} \mathrm{~Pb}(351.93 \mathrm{keV})$. The ${ }^{232} \mathrm{Th}$ activity was determined by $338.4,911.2$ and $969.1 \mathrm{keV}$ gamma lines from ${ }^{228} \mathrm{Ac}$ and its decay products. The gamma line at $1460.8 \mathrm{keV}$ was used to determine the activity of ${ }^{40} \mathrm{~K}$.

The energy and efficiency calibration of the gamma spectrometer were performed with a standard calibration source MBSS2 with Marinelli beaker geometry and an active volume of $480 \mathrm{~cm}^{3}$. The source was supplied from the Czech Metrological Institute and emitted gamma rays with the energy between 53 and $1836 \mathrm{keV}$. It contained 11 radionuclides in silicone resin $\left({ }^{241} \mathrm{Am},{ }^{109} \mathrm{Cd},{ }^{139} \mathrm{Ce},{ }^{57} \mathrm{Co}\right.$, ${ }^{60} \mathrm{Co},{ }^{137} \mathrm{Cs},{ }^{113} \mathrm{Sn},{ }^{85} \mathrm{Sr},{ }^{88} \mathrm{Y},{ }^{133} \mathrm{Ba}$, and $\left.{ }^{54} \mathrm{Mn}\right)$, and the total activity was $39.98 \mathrm{kBq}$, with an expressed measurement uncertainty of $2 \%$. In order to determine the background radioactivity in the detector environment, an empty sealed Marinelli beaker with the same geometry was measured at equal counts as the soil samples. The analysis procedure included the subtraction of the background spectrum.

Genie 2000 Gamma Analysis Software (Mirion Technologies-Canberra, Meriden, CT, USA) was used to process the obtained spectra. Statistical evaluation of the obtained data was performed using the statistical package OriginPro 8 SR4 v8.0951 software package (OriginLab Corporation, Northampton, MA, USA).

\subsection{Calculation of radium equivalent activity}

As the distribution for ${ }^{226} \mathrm{Ra},{ }^{232} \mathrm{Th}$ and ${ }^{40} \mathrm{~K}$ in soil samples is not uniform, exposure to radiation can be defined in terms of radium equivalent $\left(\mathrm{Ra}_{\mathrm{eq}}\right)$, with the aim to compare the specific activity of the radionuclides of interest [14]. The radium equivalent activity may be defined as:

$$
\mathrm{Ra}_{\mathrm{eq}}=A_{\mathrm{Ra}}+1.43 \times A_{\mathrm{Th}}+0.077 \times A_{\mathrm{K}},
$$

where $A_{\mathrm{Ra}}, A_{\mathrm{Th}}$ and $A_{\mathrm{K}}$ are the specific activities $\left(\mathrm{Bq} \mathrm{kg}^{-1}\right)$ of ${ }^{226} \mathrm{Ra},{ }^{232} \mathrm{Th}$ and ${ }^{40} \mathrm{~K}$, respectively. The
$\mathrm{Ra}_{\text {eq }}$ index expresses the specific activities of the investigated radioisotopes assuming that $370 \mathrm{~Bq}$ $\mathrm{kg}^{-1}$ of ${ }^{226} \mathrm{Ra}$, or $259 \mathrm{~Bq} \mathrm{~kg}^{-1}$ of ${ }^{232} \mathrm{Th}$, or $4810 \mathrm{~Bq}$ $\mathrm{kg}^{-1}$ of ${ }^{40} \mathrm{~K}$ produce an equal gamma dose rate [14].

\subsection{Calculation of air-absorbed dose rates $(D)$}

It is considered that for calculation of the outdoor air-absorbed dose rate due to the terrestrial gamma rays at $1 \mathrm{~m}$ above the ground, only ${ }^{226} \mathrm{Ra}$, ${ }^{232} \mathrm{Th}$ and ${ }^{40} \mathrm{~K}$ concentration values in soils should be taken into account, assuming that other radionuclides, such as ${ }^{137} \mathrm{Cs},{ }^{90} \mathrm{Sr}$ and the ${ }^{235} \mathrm{U}$ decay series reveal a negligible contribution to the total dose [14]. The conversion factors used to calculate the absorbed dose rates are the ones proposed by UNSCEAR [24]:

$$
D=0.462 \times C_{\mathrm{Ra}}+0.604 \times C_{\mathrm{Th}}+0.0417 \times C_{\mathrm{K}},(2)
$$

where $D$ is the dose rate in $\mathrm{nGy} / \mathrm{h}$, and $C_{\mathrm{Ra}}, C_{\mathrm{Th}}$ and $C_{\mathrm{K}}$ are the concentrations, expressed in $\mathrm{Bq} \mathrm{kg}^{-1}$, of ${ }^{226} \mathrm{Ra},{ }^{232} \mathrm{Th}$ and ${ }^{40} \mathrm{~K}$, respectively. The equation above is given assuming that all decay products of ${ }^{226} \mathrm{Ra}$ and ${ }^{232} \mathrm{Th}$ are in equilibrium with their precursors.

\subsection{Calculation of the external hazard index $\left(H_{e x}\right)$}

The external hazard index is calculated by equation proposed by Beretka and Matthew [14]:

$$
H_{\mathrm{ex}}=C_{\mathrm{Ra}} / 370+C_{\mathrm{Th}} / 259+C_{\mathrm{K}} / 4810 \leq 1,
$$

where $H_{\mathrm{ex}}$ is external hazard value, and $C_{\mathrm{Ra}}, C_{\mathrm{Th}}$ and $C_{\mathrm{K}}$ are the mean activity concentrations $(\mathrm{Bq}$ $\mathrm{kg}^{-1}$ ) of ${ }^{226} \mathrm{Ra},{ }^{232} \mathrm{Th}$ and ${ }^{40} \mathrm{~K}$, respectively. The value of this index must be less than unity, thus keeping the radiation hazard insignificant. The maximum value of $H_{\mathrm{ex}}$, equal to unity, corresponds to the upper limit of $\mathrm{Ra}_{\mathrm{eq}}\left(370 \mathrm{~Bq} \mathrm{~kg}^{-1}\right)$.

\subsection{Calculation of annual effective dose}

When estimating the annual effective dose received by a human individual, one has to take into consideration the conversion coefficient from the absorbed dose in air to the human effective dose, and the outdoor occupancy factor of $20 \%$. The annual effective dose rate $\left(D_{\mathrm{A}, \text { eff }}\right)$ is calculated by the equation [4]:

$$
D_{\mathrm{A}, \mathrm{eff}}=D \times N \mathrm{~h} \times 0.7 \times 0.2,
$$

where $D_{\text {A,eff }}$ is the annual effective dose in $\mu \mathrm{Sv} \mathrm{y}^{-1}$, $D$ is the air absorbed dose rate, and $N$ h is the annual number of hours (8760). Within Eq. (4) the dose 
rate data obtained from the concentration values of natural radionuclides in soil $(D)$, conversion factor of $0.7 \mu \mathrm{Sv} \mathrm{Gy}^{-1}$ from the absorbed dose in air to effective dose received by adults [4], and approximation of $20 \%$ outdoor time, are included.

\subsection{Calculation of annual gonadal equivalent dose}

According to UNCEAR [24], human organs of interest for measurable biological effects of radiation are the gonads, the active bone narrow, and the bone surface cells. Therefore, the annual gonadal equivalent dose (AGDE) for the studied population, due to the concentrations of ${ }^{226} \mathrm{Ra},{ }^{232} \mathrm{Th}$ and ${ }^{40} \mathrm{~K}$, was calculated using Eq. (5) [9]:

$$
\mathrm{AGDE}=3.09 \times C_{\mathrm{Ra}}+4.18 \times C_{\mathrm{Th}}+0.314 \times C_{\mathrm{K},}(5)
$$

where AGDE is annual gonadal equivalent dose in $\mu \mathrm{S} \mathrm{y^{-1 }}$, and $C_{\mathrm{Ra}}, C_{\mathrm{Th}}$ and $C_{\mathrm{K}}$ are the specific activities $\left(\mathrm{Bq} \mathrm{kg}{ }^{-1}\right)$ of ${ }^{226} \mathrm{Ra},{ }^{232} \mathrm{Th}$ and ${ }^{40} \mathrm{~K}$, respectively.

\subsection{Excess lifetime cancer risk}

Excess lifetime cancer risk (ELCR) is a radiological parameter which describes the additional risk of developing cancer resulting from exposure to gamma irradiation during a lifetime. It was calculated using the following equation [9]:

$$
\mathrm{ELCR}=\mathrm{AEDE} \times \mathrm{DL} \times \mathrm{RF}
$$

where AEDE, DL and RF are the annual effective dose equivalent, average duration of lifetime (70 years) and fatal risk factor $\left(\mathrm{Sv}^{-1}\right)$, respectively. For stochastic effects, the International Commission on Radiological Protection (ICRP) as a fatal risk factor recommends the value of 0.05 per Sievert for the public [25].

\section{RESULTS AND DISCUSSION}

\subsection{The activity concentrations}

The results for vertical distribution of the radionuclides throughout the soil at $0-5,5-10$ and $10-15 \mathrm{~cm}$ depth have been previously published and discussed [19]. Therefore, in Table 1, the average values of the activity concentrations for ${ }^{226} \mathrm{Ra}$, ${ }^{232} \mathrm{Th}$ and ${ }^{40} \mathrm{~K}$ obtained from six measurements (three different depths in duplicate), associated with the respective standard deviations (SD) that occur due to sampling and counting errors, are presented.
From the table we found that the standard deviation values for the three radioisotopes are less than their corresponding average, showing a high degree of uniformity of their distribution in the studied samples, as other authors have also concluded [26]. The negative values of the skewness for ${ }^{226} \mathrm{Ra}$ (Table 1), shows that the frequency distribution is slightly assymetric, i.e slightly skewed to the left, while the frequency distribution for ${ }^{232} \mathrm{Th}$ is slightly positively skewed. On the other hand, the skewness value for ${ }^{40} \mathrm{~K}$ is very close do zero, indicating that the frequency distribution curve is normal. Besides that, the kurtosis for the activity concentrations of the investigated radionuclides have negative values, showing that the frequency distribution curve is less peaked than the normal curve for each of the radioisotopes ${ }^{226} \mathrm{Ra}$, ${ }^{232} \mathrm{Th},{ }^{40} \mathrm{~K}$. This may be attributed to the unequal distribution of the investigated natural radioisotopes in the soil samples from the agricultural area in Skopje city surroundings.

As expected, and in accordance with the worldwide data [4], the activities for ${ }^{232} \mathrm{Th}$ are higher than the ones for ${ }^{226} \mathrm{Ra}$, while the values for ${ }^{40} \mathrm{~K}$ are one magnitude higher. The activity concentrations of ${ }^{226} \mathrm{Ra},{ }^{232} \mathrm{Th}$ and ${ }^{40} \mathrm{~K}$ ranged from $24.1 \pm$ $0.6 \mathrm{~Bq} \mathrm{~kg}^{-1}$ to $41.9 \pm 5.6 \mathrm{~Bq} \mathrm{~kg}^{-1}$, from $38.5 \pm 2.5$ $\mathrm{Bq} \mathrm{kg}^{-1}$ to $52.2 \pm 1.6 \mathrm{~Bq} \mathrm{~kg}^{-1}$ and from $502 \pm 55$ $\mathrm{Bq} \mathrm{kg}^{-1}$ to $707 \pm 14 \mathrm{~Bq} \mathrm{~kg}^{-1}$, respectively. In comparison to the worldwide median values for ${ }^{226} \mathrm{Ra}$ $35 \mathrm{~Bq} \mathrm{~kg}{ }^{-1}$ [4], the measured activities for locations $3,4,6,7,8,9,12$ and 13 revealed higher ${ }^{226} \mathrm{Ra}$ values. However, the average ${ }^{226} \mathrm{Ra}$ value for all 14 locations $\left(34.1 \mathrm{~Bq} \mathrm{~kg}^{-1} \pm 6.0 \mathrm{~Bq} \mathrm{~kg}^{-1}\right)$ is practically equal to the worldwide median value (35 Bq kg$~^{-1}$ ). On the other hand, all values measured for ${ }^{232} \mathrm{Th}$ were higher than the world average (30 $\mathrm{Bq} \mathrm{kg}^{-1}$ ) [4]. Regarding the ${ }^{40} \mathrm{~K}$ activities, similarly to ${ }^{232} \mathrm{Th}$, all values revealed are higher than the worldwide average value, reported to be 400 $\mathrm{Bq} \mathrm{kg}^{-1}$ [4]. The data ranges for ${ }^{226} \mathrm{Ra},{ }^{232} \mathrm{Th}$ and ${ }^{40} \mathrm{~K}$ determined within this study are lower than the ones determined by other authors [7, 10, 11, 15] and the ranges reported by UNCEAR for findings in different countries worldwide [4].

This is probably due to the fact that the studied area is smaller (around $2100 \mathrm{~km}^{2}$ ) in comparison to other studies $[10,11,16]$. For this reason, the factors mainly affecting the radionuclide distribution in soils (geographical, geological and hydrological) have a low variability (less than $20 \%$ relative standard deviation), resulting in a relatively higher uniformity in the ${ }^{226} \mathrm{Ra},{ }^{232} \mathrm{Th}$ and ${ }^{40} \mathrm{~K}$ distribution on 
the territory of Skopje city surroundings. Even though the worldwide average concentrations of radionuclides in soils are low, there is a large variability of the data reported, with revealed levels up to $1000 \mathrm{~Bq} \mathrm{~kg}{ }^{-1}$ for ${ }^{238} \mathrm{U}, 360 \mathrm{~Bq} \mathrm{~kg}{ }^{-1}$ for ${ }^{232} \mathrm{Th}$ and $3200 \mathrm{~Bq} \mathrm{~kg}^{-1}$ for ${ }^{40} \mathrm{~K}$ (UNSCEAR, 2008) [27]. Therefore, for the purposes of global dose assessment, the data presented needs to be linked with the respective population distributions.

\section{Table 1}

Measurement data and descriptive statistics for specific activities of ${ }^{226} \mathrm{Ra},{ }^{232} \mathrm{Th}$, and ${ }^{40} \mathrm{~K}$ in soil samples

\begin{tabular}{clccc}
\hline \hline \multirow{2}{*}{$\begin{array}{c}\text { Location } \\
\text { No. }\end{array}$} & Sampling site & \multicolumn{2}{c}{ Activity concentrations $\pm \mathrm{SD}\left(\mathrm{Bq} \mathrm{kg}^{-1}\right)^{*}$} \\
\cline { 2 - 4 } 1 & Petrovec & $34.4 \pm 4.2$ & $42.4 \pm 4.2$ & $588 \pm 11$ \\
2 & Belimbegovo & $32.4 \pm 3.3$ & $42.5 \pm 1.2$ & $574 \pm 16$ \\
3 & Aračinovo & $41.2 \pm 1.8$ & $48.1 \pm 1.2$ & $677 \pm 18$ \\
4 & Radišani & $31.4 \pm 1.2$ & $51.5 \pm 2.7$ & $623 \pm 9$ \\
5 & Čučer-Sandevo & $24.1 \pm 0.6$ & $38.5 \pm 2.5$ & $502 \pm 55$ \\
6 & Vizbegovo & $40.8 \pm 1.0$ & $49.6 \pm 1.7$ & $705 \pm 17$ \\
7 & Bardovci & $41.9 \pm 5.6$ & $49.8 \pm 2.2$ & $707 \pm 14$ \\
8 & Saraj & $36.0 \pm 0.5$ & $41.0 \pm 1.9$ & $629 \pm 19$ \\
9 & Nerezi & $36.3 \pm 1.3$ & $52.2 \pm 1.6$ & $624 \pm 16$ \\
10 & Lisiče & $26.3 \pm 1.4$ & $40.8 \pm 2.1$ & $527 \pm 39$ \\
11 & Dračevo & $25.7 \pm 1.6$ & $39.9 \pm 1.5$ & $549 \pm 24$ \\
12 & Pintija & $40.9 \pm 1.2$ & $46.0 \pm 3.3$ & $656 \pm 26$ \\
13 & Batinci & $36.0 \pm 4.2$ & $42.4 \pm 1.2$ & $630 \pm 32$ \\
14 & Volkovo & $29.3 \pm 5.1$ & $41.9 \pm 3.6$ & $526 \pm 72$ \\
\hline \multicolumn{7}{c}{ Average \pm SD** } & $34.0 \pm 6.1$ & $44.7 \pm 4.6$ & $608 \pm 66$ \\
& Median & 35.2 & 42.4 & 623 \\
& Minimum & 24.1 & 38.5 & 502 \\
& Maximum & 41.9 & 52.2 & 707 \\
& Range (max-min) & 17.8 & 13.5 & 205 \\
& Skewness & -0.27 & 0.42 & -0.07 \\
\hline \hline
\end{tabular}

\section{*Average values of 6 measurements $\pm \mathrm{SD}$}

**SD - standard deviation

Nevertheless, when comparing our results with the published values for the surrounding countries on the Balkan Peninsula, one may conclude that they are more or less similar. Thus, the published data for Serbia ranged between $26.77 \pm 1.4 \mathrm{~Bq} \mathrm{~kg}^{-1}$ and $38 \pm$ $2.3 \mathrm{~Bq} \mathrm{~kg}^{-1}$ for ${ }^{226} \mathrm{Ra}, 2.97 \pm 9.4 \mathrm{~Bq} \mathrm{~kg}^{-1}$ and $53 \pm 8$ $\mathrm{Bq} \mathrm{kg}{ }^{-1}$ for ${ }^{232} \mathrm{Th}$, and $457 \pm 192 \mathrm{~Bq} \mathrm{~kg}^{-1}$ and $554 \pm 92$ $\mathrm{Bq} \mathrm{kg}{ }^{-1}$ for ${ }^{40} \mathrm{~K}$ [28-31]. The data reported for Bulgaria are similar for ${ }^{226} \mathrm{Ra}$ and ${ }^{232} \mathrm{Th}(45$ and 30 $\left.\mathrm{Bq} \mathrm{kg}{ }^{-1}\right)$, but are lower for ${ }^{40} \mathrm{~K}\left(400 \mathrm{~Bq} \mathrm{~kg}^{-1}\right)$ [4]. The available data for Greece revealed significantly lower levels of activity concentrations, being $25 \mathrm{~Bq} \mathrm{~kg}^{-1}, 21$ $\mathrm{Bq} \mathrm{kg}{ }^{-1}$ and $360 \mathrm{~Bq} \mathrm{~kg}^{-1}$ for ${ }^{226} \mathrm{Ra},{ }^{232} \mathrm{Th}$ and ${ }^{40} \mathrm{~K}$, respectively [4]. The same conclusion is true for the natural radiactivity in soils from Albania; the concentrations determined were $19 \pm 5 \mathrm{~Bq} \mathrm{~kg}^{-1}$ for ${ }^{226} \mathrm{Ra}, 20 \pm 5 \mathrm{~Bq} \mathrm{~kg}^{-1}$ for ${ }^{232} \mathrm{Th}$ and $297 \pm 5 \mathrm{~Bq} \mathrm{~kg}^{-1}$ for ${ }^{40} \mathrm{~K}$ [32]. As reported, the activity concentration results for Croatia were higher for ${ }^{226} \mathrm{Ra}$ and ${ }^{232} \mathrm{Th}$ $\left(73.3 \pm 15.8 \mathrm{~Bq} \mathrm{~kg}\right.$ and $61.8 \pm 13.4 \mathrm{~Bq} \mathrm{~kg}{ }^{-1}$, respectively), but were close for ${ }^{40} \mathrm{~K}\left(645 \mathrm{~Bq} \mathrm{~kg}^{-1} \pm\right.$ $61.4 \mathrm{~Bq} \mathrm{~kg}^{-1}$ ) [33]. According to the UNCEAR data base [4], the levels of ${ }^{226} \mathrm{Ra},{ }^{232} \mathrm{Th}$ and ${ }^{40} \mathrm{~K}$ in Romania were 32,38 and $490 \mathrm{~Bq} \mathrm{~kg}^{-1}$, respectively, being very close to our results for ${ }^{226} \mathrm{Ra}$ and ${ }^{232} \mathrm{Th}$, but lower for ${ }^{40} \mathrm{~K}$. In comparison to the previously published average data for the Kavadarci region from Macedonia $\left(35.5,39.2\right.$ and $516 \mathrm{~Bq} \mathrm{~kg}^{-1}$ for ${ }^{226} \mathrm{Ra}$, ${ }^{232} \mathrm{Th}$ and ${ }^{40} \mathrm{~K}$, respectively) [21, 22], the results from this study seem to be quite similar.

The latest UNSCEAR data for the worldwide natural radionuclides concentrations in soil samples [27], as well as some data published from other authors $[9,15,16,34-40]$ are presented in Table 2. 
T a ble 2

Comparison of natural radioactivity levels in soil and air-absorbed doses at different world locations and our study

\begin{tabular}{|c|c|c|c|c|}
\hline \multirow{2}{*}{ Country (Region) [Ref.] } & \multicolumn{3}{|c|}{ Activity concentrations range $\left(\mathrm{Bq} \mathrm{kg}^{-1}\right)$} & \multirow{2}{*}{$\begin{array}{l}\text { Absorbed dose rate } \\
\quad\left(\mathrm{nGy} \mathrm{h}^{-1}\right)\end{array}$} \\
\hline & ${ }^{226} \mathrm{Ra}$ & ${ }^{232} \mathrm{Th}$ & ${ }^{40} \mathrm{~K}$ & \\
\hline Indonesia [27] & $2.4-422$ & $0.5-66$ & $48-252$ & $33-224(97)^{*}$ \\
\hline $\begin{array}{l}\text { Islamic Republic of Iran (Ram- } \\
\text { sar) [27] }\end{array}$ & $80-50000$ & $15-47$ & $300-945$ & $80-100000(765)^{*}$ \\
\hline $\begin{array}{l}\text { Islamic Republic of Iran (Ma- } \\
\text { hallat) [27] }\end{array}$ & $500-7300$ & $15-41$ & $364-873$ & $300-3800$ \\
\hline Azerbaijan [27] & $500-2500$ & $100-1000$ & $800-1000$ & $877-8770$ \\
\hline Indonesia (Bankog Island) [27] & - & - & - & $90-540(330)^{*}$ \\
\hline Indonesia (Karimi Island) [27] & - & - & - & $200-410(310)^{*}$ \\
\hline Phillipines [27] & - & - & - & $75-1558(300)^{*}$ \\
\hline Russian Federation [27] & $100-150$ & $10-160$ & - & up to 300 \\
\hline Spain [27] & $60-250$ & $42-71$ & $810-1240$ & $136-260$ \\
\hline Switzerland [27] & - & - & - & $100-200$ \\
\hline Saudi Arabia [34] & $17-28(23)^{*}$ & $1.1-81(20)^{*}$ & $218-255(233)^{*}$ & $17-72(33)^{*}$ \\
\hline Palestine (Tulkarem) [16] & - & $5.3-44.8(23.8)^{*}$ & $10.2-404(120)^{*}$ & $11.5-82.7(35.5)^{*}$ \\
\hline Oman (Musandam) [35] & $5-26(14)^{*}$ & $1-20(10)^{*}$ & $10-283(158)$ & $4-35(19)^{*}$ \\
\hline Egypt (Dakahlia) [9] & $5.7-140(43)^{*}$ & $9-139(54)^{*}$ & $22-319(183) 8$ & $51-166(62)^{*}$ \\
\hline Iran (Teheran) [36] & $30.5-45.4(38.8)^{*}$ & $27.3-57.1(43.4)^{*}$ & $\begin{array}{l}328.0-768.5 \\
(555.1)^{*}\end{array}$ & $48.1-88.7$ \\
\hline Pakistan (Sind) [37] & $18-47$ & $24-69$ & $254-769$ & $33-87$ \\
\hline Kenya (Mount Homa) [38] & $17-1447(195)^{*}$ & $23-1369(409) *$ & 64-3017 (915)* & $154.8-2280.6$ \\
\hline Thailand (Hat Yai) [15] & $\begin{array}{l}25.73-156.06 \\
(67.66)^{*}\end{array}$ & $\begin{array}{l}6.77-91.28 \\
(45.00)^{*}\end{array}$ & $\begin{array}{l}62.40-949.44 \\
(213.05)^{*}\end{array}$ & $35.36-160.19(68.4)^{*}$ \\
\hline Turkey (Anatolia) [39] & - & $27-100(27.2)^{*}$ & $255-1273(524) *$ & $21.8-81.3(47.0)^{*}$ \\
\hline Turkey (Marmara region) [40] & $4.2-86.95(22.45)^{*}$ & $\begin{array}{l}4.6-88.85 \\
(26.63)^{*}\end{array}$ & $\begin{array}{c}69.2-1085.6 \\
(442.51)^{*}\end{array}$ & 54.86 \\
\hline Belgrade (Serbia) [31] & $33.6^{*}$ & $39.3 *$ & $508 *$ & $60.5^{*}$ \\
\hline Egypt (Mueilha area) [26] & $121.28 *$ & $82.19^{*}$ & $839.97 *$ & $34.12 *$ \\
\hline Present study & $24.1-41.9(34.1)^{*}$ & $38.5-52.2(44.9)^{*}$ & $\begin{array}{c}502-707 \\
(614)^{*} \\
\end{array}$ & $55.5-79.1(68.5)^{*}$ \\
\hline
\end{tabular}

*Average values

\subsection{Estimation of radiological effects}

The air-absorbed dose rates, calculated from the activity concentrations data for ${ }^{226} \mathrm{Ra},{ }^{232} \mathrm{Th}$ and ${ }^{40} \mathrm{~K}$ (Table 1), applying the corresponsive equation (Eq. 2), are presented in Table 2. The ranges calculated varied between $11.1 \mathrm{nGy} \mathrm{h}^{-1}$ and $19.4 \mathrm{nGy} \mathrm{h}^{-1}$, $23.3 \mathrm{nGy} \mathrm{h}^{-1}$ and $30.1 \mathrm{nGy} \mathrm{h}^{-1}$, and $55.5 \mathrm{nGy} \mathrm{h}^{-1}$ and $79.1 \mathrm{nGy} \mathrm{h}^{-1}$, for ${ }^{226} \mathrm{Ra},{ }^{232} \mathrm{Th}$ and ${ }^{40} \mathrm{~K}$, respectively. The calculated average air-absorbed dose was $68.5 \pm 8.1 \mathrm{nGy} \mathrm{h}^{-1}$, being higher than the world average value for terrestrial radiation, which is estimated at $60 \mathrm{nGy} \mathrm{h}^{-1}$ [4]. The average estimated absorbed dose within this study was compared with the worldwide published data (Table 2). However, this value remains under $1000 \mu \mathrm{Sv} \mathrm{y}^{-1}$, which is the recommended maximal dose criterion by ICRP [25].
On the basis of equations 1 and 3-6, the values for radium equivalent activity, external hazard index, annual effective dose, annual gonadal dose and excess lifetime cancer risk for the different sampling locations in the Skopje city region were calculated. As can be seen from the presented data (Table 4), the radium equivalent activity values for the soil samples varied from $114 \mathrm{~Bq} \mathrm{~kg}^{-1}$ in ČučerSandevo to $163 \mathrm{~Bq} \mathrm{~kg}^{-1}$ in Bardovci, with an average value of $143 \pm 16 \mathrm{~Bq} \mathrm{~kg}^{-1}$. These values are lower than $370 \mathrm{~Bq} \mathrm{~kg}{ }^{-1}$ which is considered as the safe radium equivalent level for the population [11]. The variation of the $\mathrm{Ra}_{\mathrm{eq}}$ values is attributed to the mineralogical alteration processes affecting the studied soils [26], and additional contamination with naturally occurring radionuclides from soil fertilizers [41]. 
Table 3

Air-absorbed dose rates for ${ }^{226} \mathrm{Ra},{ }^{232} \mathrm{Th}$ and ${ }^{40} \mathrm{~K}$ at various locations in the Skopje city region

\begin{tabular}{|c|c|c|c|c|c|}
\hline \multirow{2}{*}{$\begin{array}{c}\text { Location } \\
\text { No. }\end{array}$} & \multirow{2}{*}{ Sampling site } & \multicolumn{4}{|c|}{ Absorbed gamma dose rate $\left(\mathrm{nGy} \mathrm{h}^{-1}\right)$} \\
\hline & & ${ }^{226} \mathrm{Ra}$ & ${ }^{232} \mathrm{Th}$ & ${ }^{40} \mathrm{~K}$ & Total \\
\hline 1 & Petrovec & 15.9 & 25.6 & 24.5 & 66.0 \\
\hline 2 & Belimbegovo & 15.0 & 25.6 & 23.9 & 64.5 \\
\hline 3 & Aračinovo & 19.0 & 29.0 & 28.2 & 76.3 \\
\hline 4 & Radišani & 14.5 & 31.1 & 26.0 & 71.6 \\
\hline 5 & Čučer-Sandevo & 11.1 & 23.3 & 20.9 & 55.3 \\
\hline 6 & Vizbegovo & 18.8 & 29.9 & 29.4 & 78.2 \\
\hline 7 & Bardovci & 19.4 & 30.1 & 29.5 & 79.0 \\
\hline 8 & Saraj & 16.7 & 24.7 & 26.2 & 67.6 \\
\hline 9 & Nerezi & 16.9 & 31.5 & 26.0 & 74.3 \\
\hline 10 & Lisiče & 12.1 & 24.6 & 22.0 & 58.7 \\
\hline 11 & Drachevo & 11.9 & 24.1 & 22.9 & 58.9 \\
\hline 12 & Pintija & 18.9 & 27.8 & 27.4 & 74.0 \\
\hline 13 & Batinci & 16.6 & 25.6 & 26.3 & 68.5 \\
\hline \multirow[t]{6}{*}{14} & Volkovo & 13.5 & 25.3 & 21.9 & 60.8 \\
\hline & Average \pm SD* & $15.7 \pm 2.8$ & $27.0 \pm 2.8$ & $25.4 \pm 2.8$ & $68.1 \pm 7.7$ \\
\hline & Median & 16.3 & 25.6 & 26.0 & 68.0 \\
\hline & Minimum & 11.1 & 23.3 & 21.9 & 55.3 \\
\hline & Maximum & 19.4 & 30.1 & 29.5 & 79.0 \\
\hline & Range (max-min) & 8.3 & 6.8 & 7.6 & 23.7 \\
\hline
\end{tabular}

*Average value from all sampling sites \pm standard deviation

Table 4

Radium equivalent $\left(R a_{e q}\right)$, external hazard index $\left(H_{\text {eks }}\right)$, annual effective dose $\left(D_{A}\right.$,eff $)$, annual gonadal dose equivalent (AGDE), and excess lifetime cancer risk (ELCR)

\begin{tabular}{clccccc}
\hline \hline Location & Sampling site & Raeq & $H_{\text {eks }}$ & $D_{\text {A,eff }}$ & AGDE & \\
\hline 1 & Petrovec & 136 & 0.38 & 80.9 & 468 & 0.31 \\
2 & Belimbegovo & 133 & 0.37 & 79.1 & 458 & 0.31 \\
3 & Aračinovo & 157 & 0.44 & 93.6 & 541 & 0.36 \\
4 & Radišani & 149 & 0.41 & 87.7 & 508 & 0.34 \\
5 & Čučer-Sandevo & 114 & 0.32 & 67.8 & 393 & 0.26 \\
6 & Vizbegovo & 161 & 0.45 & 95.9 & 554 & 0.37 \\
7 & Bardovci & 163 & 0.45 & 96.8 & 560 & 0.37 \\
8 & Saraj & 139 & 0.39 & 82.9 & 480 & 0.32 \\
9 & Nerezi & 155 & 0.43 & 91.1 & 526 & 0.35 \\
10 & Lisiče & 125 & 0.34 & 72.0 & 490 & 0.33 \\
11 & Drachevo & 125 & 0.33 & 72.2 & 419 & 0.28 \\
12 & Pintija & 157 & 0.43 & 90.7 & 524 & 0.35 \\
13 & Batinci & 141 & 0.39 & 84.0 & 486 & 0.32 \\
14 & Volkovo & 126 & 0.35 & 74.6 & 431 & 0.29 \\
\hline & Range & 48 & 0.12 & 24.8 & 141 & 0.11 \\
& Average* SD & $143 \pm 16$ & $0.39 \pm 0.05$ & $83.5 \pm 9.5$ & $493 \pm 50$ & $0.33 \pm 0.03$ \\
& Median & 141 & 0.39 & 83.4 & 490 & 0.33 \\
& Minimum & 114 & 0.33 & 72.0 & 419 & 0.26 \\
\hline \hline
\end{tabular}

*Average value from all sampling sites 
The ultimate purpose of the radionuclides measurement in the soil samples is to assess the radiation dose delivered externally to the population in the form of gamma dose. The calculated values for the radiation risk index $\left(H_{\mathrm{ex}}\right)$ for the soil samples analyzed within this study were within the range from 0.33 to 0.45 , with an average of $0.39 \pm 0.05$ (Table 4). Since all these calculated values are lower than unity, as desired, they may be considered as safe for exploitation as agricultural soils.

The average annual effective dose was found to be $83.5 \pm 9.5 \mu \mathrm{Sv}$, using the respective conversion factor $\left(0.7 \mathrm{~Sv} \mathrm{~Gy}{ }^{-1}\right)$ and the outdoor occupancy factor of 0.2 [40]. The lowest annual effective dose was calculated for Lisiče $(72.0 \mu \mathrm{Sv})$ and the highest at the location of Bardovci (96.8 $\mu \mathrm{Sv}$ ) (Table 4). The calculated average effective dose was higher than the world average $(70 \mu \mathrm{Sv})$ [4]. Accordingly, the effective dose average within this study was higher than the values revealed from most of the investigations conducted in Turkey (49 $\mu \mathrm{Sv}, 54.86 \mu \mathrm{Sv}$ and $57.7 \mu \mathrm{Sv})[39,40]$ and Egypt (76 $\mu \mathrm{Sv}$ ) [9]. However, the calculated annual effective dose was lower than the values obtained for India $(105.9 \mu \mathrm{S})$ [11] and Iran $(193.15 \mu \mathrm{Sv})$ [36].The annual effective dose that we determined for the Skopje city region (Republic of Macedonia) was very close to the one previously determined for the city of Kavadarci (Republic of Macedonia), estimated at $82 \pm 26 \mu \mathrm{Sv}$ [21,22].

The annual gonadal dose equivalent (AGDE, $\left.\mu \mathrm{Sv} \mathrm{y}^{-1}\right)$ due to the specific activities of ${ }^{226} \mathrm{Ra}$,
${ }^{233} \mathrm{Ra}$ and ${ }^{40} \mathrm{~K}$, calculated applying Eq. (5), varied within the values from 419 (location Dračevo) to $560 \mu \mathrm{Sv} \mathrm{y}^{-1}$ (location Bardovci), with an average value of $(493 \pm 50) \mu \mathrm{Sv} \mathrm{y}^{-1}$ (Table 4). The calculated AGDE was lower than the recommended ICRP equivalent limit of $1000 \mu \mathrm{Sv}^{-1}$ for the general public [25]. However, the average value obtained was higher than the reported values for agricultural soils in Egypt $\left(76 \mu \mathrm{Sv} \mathrm{y}^{-1}\right)$ [9] and Palestine $\left(230 \mu \mathrm{Sv} \mathrm{y}^{-1}\right)$ [16].

Excess lifetime cancer risks (ELCR), calculated by $\mathrm{Eq}(6)$ revealed range values from $0.26-$ $0.36 \times 10^{-3}$. The calculated average value is $0.33 \pm$ $0.03 \times 10^{-3}$, which is somewhat higher than the word average estimated at $0.29 \times 10^{-3}$ [4], but still, the indices for cancer risk are negligible. The lowest ELCR value $\left(0.26 \times 10^{-3}\right)$ was estimated for the location Čučer-Sandevo, while the highest values were for Vizbegovo and Bardovci $\left(0.37 \times 10^{-3}\right)$. As a comparison, some worldwide estimated ELCR values were $0.59 \times 10^{-3}$ for South Eastern Desert, Egypt [26], $0.29 \times 10^{-3}$ for Dakahlia province, Egypt [9], $0.28 \times 10^{-3}$ for Vojvodina province in Serbia [31], and $0.95 \times 10^{-3}$ found for Palestine [16].

\subsection{Pearson's correlation analysis}

The statistical analysis of the Pearson correlation coefficient was performed between the activity concentrations of the three radioisotopes of interest in this study, and the radiological variables arising from them (Table 5).

\section{Table 5}

Pearson's correlation coefficients between radioisotopes and related radiological variables

\begin{tabular}{|c|c|c|c|c|c|c|c|c|c|}
\hline Variables & ${ }^{226} \mathrm{Ra}$ & 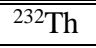 & 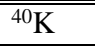 & $\begin{array}{l}\text { AGDR } \\
\end{array}$ & Raeq & $H_{\mathrm{ex}}$ & $D_{\mathrm{A}, \mathrm{eff}}$ & $\overline{\text { AGDE }}$ & $\bar{E} \mathrm{ELCR} \times 10^{-3}$ \\
\hline${ }^{226} \mathrm{Ra}$ & 1.000 & & & & & & & & \\
\hline${ }^{232} \mathrm{Th}$ & 0.659 & 1.000 & & & & & & & \\
\hline${ }^{40} \mathrm{~K}$ & 0.545 & 0.543 & 1.000 & & & & & & \\
\hline AGDR & 0.939 & 0.866 & 0.569 & 1.000 & & & & & \\
\hline Raeq & 0.927 & 0.873 & 0.558 & 0.994 & 1.000 & & & & \\
\hline$H_{\mathrm{ex}}$ & 0.942 & 0.866 & 0.558 & 0.997 & 0.992 & 1.000 & & & \\
\hline$D_{\mathrm{A}, \mathrm{eff}}$ & 0.939 & 0.866 & 0.569 & 1.000 & 0.994 & 0.997 & 1.000 & & \\
\hline AGDE & 0.860 & 0.829 & 0.600 & 0.933 & 0.945 & 0.938 & 0.933 & 1.000 & \\
\hline$E L C R \times 10^{-3}$ & 0.845 & 0.830 & 0.583 & 0.922 & 0.937 & 0.928 & 0.923 & 0.997 & 1.000 \\
\hline
\end{tabular}

The correlation between ${ }^{226} \mathrm{Ra}$ and ${ }^{232} \mathrm{Th}$ displayed a good positive value $(r=0.659)$, because ${ }^{226} \mathrm{Ra}$ as a product of the ${ }^{238} \mathrm{U}$ decay and ${ }^{232} \mathrm{Th}$ decay chains, are associated together in nature [26]. A weak correlation noted between ${ }^{40} \mathrm{~K}$ and ${ }^{226} \mathrm{Ra}$, and ${ }^{40} \mathrm{~K}$ and ${ }^{232} \mathrm{Th}$, with a small positive Pearson's coefficient ( 0.545 and 0.543 , respectively), is due to the fact that ${ }^{40} \mathrm{~K}$ does not belong to the ${ }^{238} \mathrm{U}$ and ${ }^{232} \mathrm{Th}$ chains [26]. The activity concentrations of ${ }^{226} \mathrm{Ra}$ and ${ }^{232} \mathrm{Th}$ had a high positive correlation with the radiological variables $(r \geq 0.829)$, but a weak correlation between ${ }^{40} \mathrm{~K}$ and the respective varia- 
bles $(r \leq 0.6)$. Accordingly, the activity concentrations of ${ }^{238} \mathrm{U}$ and ${ }^{232} \mathrm{Th}$ were significantly related and mainly responsible for the radiological risks.

\section{CONCLUSION}

Gamma ray spectrometry was used to determine the activity concentration due to the naturally ocurring ${ }^{226} \mathrm{Ra},{ }^{232} \mathrm{Th}$ and ${ }^{40} \mathrm{~K}$ radioisotopes and the associated radiation hazard levels in 14 soil samples from the surroundings of Skopje City (North Macedonia). The estimated average concentrations for ${ }^{226} \mathrm{Ra},{ }^{232} \mathrm{Th}$ and ${ }^{40} \mathrm{~K}$ were $34.0 \pm$ $6.1 \mathrm{~Bq} \mathrm{~kg}^{-1}, 44.7 \pm 4.6 \mathrm{~Bq} \mathrm{~kg}^{-1}$ and $608 \pm 66 \mathrm{~Bq}$ $\mathrm{kg}^{-1}$, respectively. The average ${ }^{226} \mathrm{Ra}$ value was practically equal to the worldwide average, while the activities for ${ }^{232} \mathrm{Th}$ and ${ }^{40} \mathrm{~K}$ were higher than the reported average world values. Similarly, the respective average dose rates and other calculated hazard indices were higher than the average world values, however, they did not pose health risks to the population of the area studied. The total annual effective dose was lower than the value of 1000 $\mu \mathrm{Sv} \mathrm{y}^{-1}$, the dose limit recommended by the ICRP for radiation exposure of the public. This study also revealed that the risk of cancer is negligible in the region under investigation. The results for activity concentrations and the associated radiological risks obtained within this study are comparable with other studies carried out in the regionally close countries. The activity concentrations for ${ }^{238} \mathrm{U}$ and ${ }^{232} \mathrm{Th}$ were significantly related and may be considered as the main contributors to the radiological risks. In conclusion, the results from this study are significant for the assessment of naturally occuring radioactivity and the possible radiological risks coming out from the agricultural soils in the Skopje city surroundings. Additionally, the obtained results provide the necessary baseline information on radiation levels in any environment for the implementation of precautionary measures whenever the findings reveal doses above the expected one.

\section{REFERENCES}

[1] United Nations Scientific Committe on the Effects of Atomic Radiations (UNSCEAR). Sources, Effects and Risks of Ionizing Radiation. Report of the General Assembly, United Nations, New York, 1998.

[2] K. L. Bocock, Radionuclides in Terrestrial Ecosystems: A Review on the Distribution and Movement, Institute of Terrestrial Ecology, Merlewood Research Station, Cumbria, 1981.

[3] M. Tzortzis, E. Svoukis H. Tsetos, A comprehensive study of natural gamma radioactivity levels and associated dose rates from surface soils in Cyprus, Radiat. Prot. Dosim. 109 (3), 217-22 (2004).

DOI: $10.1093 / \mathrm{rpd} / \mathrm{ncq} 193$

[4] United Nations Scientific Committe on the Effects of Atomic Radiations, (UNSCEAR). Sources, Effects and Risks of Ionizing Radiation. Report of the General Assembly, United Nations, New York, 2000.

[5] M. Iqbal, M. Tufail, S. M. Mirza, Measurement of natural radioactivity in marble found in Pakistan using a $\mathrm{NaI}(\mathrm{Tl})$ gamma-ray spectrometer, Technical note, $J$. Environ. Radioact. 51 (2), 255-265 (2000). DOI: $10.1016 / \mathrm{S} 0265-931 \mathrm{X}(00) 00077-1$

[6] M. J. Anagnostakis, E. P. Hinis, S. E. Simopoulos, M. G. Angelopoulos, Natural radioactivity mapping of Greek surface soils, Environ. Int. 22 (sup 1), 3-8 (1996). DOI: https://doi.org/10.1016/S0160-4120(96)00085-2

[7] I. R. Ajayi, An evaluation of the equivalent dose due to natural radioactivity in the soil around the consolidated Tin mine in Baukuru-Jos, plateau state of Nigeria, Iran. J. Radiat. Res. 5 (4), 203-206 (2008).

[8] M. A. Shender, Measurement of natural radioactivity levels in soil in Tripoli, Appl. Radiat. Isotopes. 48 (1), 147-148 (1997).

DOI: 10.10.1016/S0969-8043(96)00065-6

[9] S. A. M. Issa, Radiometric assessment of natural radioactivity levels of agricultural soil samples collected in Dakahlia, Egypt, Radiat. Prot. Dosim. 156 (1), 59-67 (2013). DOI:10.1093/rpd/nct039

[10] A. K. Ademola, A. K. Bello, A. C. Adejumobi, Determination of natural radioactivity and hazard in soil, samples in and around gold mining area in Itagunmodi, south-western Nigeria, J. Radiat. Res. Appl. Sci. 7, 249255 (2014).

DOI: https://doi.org/10.1016/j.jrras.2014.06.001

[11] S. Singh, A. Rani, R. K. Mahajan, ${ }^{226} \mathrm{Ra},{ }^{232} \mathrm{Th}$ and ${ }^{40} \mathrm{~K}$ in soil samples from some areas of Punjab and Himachal Pradesh, India, using gamma ray spectrometry, Radiat. Meas. 39, 431-439 (2005). DOI: 10.1016/j.radmeas.2004.09.003

[12] N. Akhtar, M. Tufail and M. Asraf, Natural environmental radioactivity and estimation of radiation exposure from saline soils, Int. J. Environ. Sci. Tech. 1(4) 279285 (2005). DOI: 10.4236/ojss.2012.21002

[13] I. H. Saleh, Radioactivity of ${ }^{238} \mathrm{U},{ }^{232} \mathrm{Th},{ }^{40} \mathrm{~K}$, and ${ }^{137} \mathrm{Cs}$ and assessment of depleted uranium in soil of the $\mathrm{Mu}-$ sandam Peninsula, Sultanate of Oman, Turkish J. Eng. Env. Sci. 36, 236-248 (2012). DOI:10.3906/muh-1110-1

[14] J. Beretka, P. J. Methew, Natural radioactivity of Australian building materials, industrial wastes and byproducts, Health Phys. 48, 87-95 (1985). DOI: 16.10.1097/00004032-198501000-00007

[15] P. Kessaratikoon, S. Awaekachi, Natural radioactivity measurements in soil samples collected from municipal area of Hat Yai district in Songkhila province, Thailand, KMITL Sci. J. 8(2) Section A, 52-58 (2008).

[16] K. M. Thabayneh, M. M. Jazzar, Natural radioactivity levels and estimation of radiation exposure in environmental soil samples from Tulkarem Province - Palestine, Open Journal of Soil Science, 2, 7-16 (2012). DOI: http://dx.doi.org/10.4236/ojss.2012.21002 
[17] State Statistical Office of Republic of Macedonia. Macedonia in Figures 2013.

(www.stat.gov.mk/Publikacii/MK-Brojki_2013_a.pdf, retrieved 12.10.2015).

[18] Z. Stojanovska, D. Nedelkovski, M. Ristova, Natural radioactivity, and human exposure by raw materials and end products from cement industry used as building materials, Radiat. Meas. 45, 969-972 (2010).

DOI: https://doi.org/10.1016/j.radmeas.2010.06.023

[19] A. Angjeleska, Lj. Angelovski, R. Uzunov, E. Dimitrieska-Stojković, B. Stojanovska-Dimzoska, Z. HajrulaiMusliu, Lj. Arsov, Determination of the vertical distribution of ${ }^{226} \mathrm{Ra},{ }^{232} \mathrm{Th},{ }^{40} \mathrm{~K}$ and ${ }^{137} \mathrm{Cs}$ in samples of cultivated soil taken in the vicinity of certain cities on Republic of Macedonia, Agriculture \& Forestry (Podgorica), 60 (3), 97-106 (2014). UDC 21.634.438(497.7). DOI: $10.17707 /$ AgricultForest

[20] A. Angjeleska, E. Dimitrieska-Stojkovic, Z. HajrulaiMusliu, S. Bogoevski, B. Boskovski, B. StojanovskaDimzoska, R. Uzunov, Natural radioactivity of uncultivated soil from the surrounding of the city of Skpje, Journal of Environmental Protection and Ecology, 17(3), 1177-1184 (2016).

[21] S. Dimovska, T. Stafilov, R. Šajn, M. Frontasyeva, Distribution of some natural and man-made radionuclides in soil from the city of Veles (Republic of Macedonia) and its environs, Radiat. Prot. Dosim. 138 (2) 144-157 (2010). DOI: 10.1093/rdp/ncp238

[22] S. Dimovska, T. Stafilov, R. Šajn, Radioactivity in soil from the city of Kavadarci (Republic of Macedonia) and its environs, Radiat. Prot. Dosim. 148 (1) 107-120 (2011). DOI: $10.1093 /$ rpd/ncq601

[23] International Atomic Energy Agency. Measurement of radionuclides in food and the environment, A guidebook, IAEA Technical Report 295, Vienna, Austria, 1989.

[24] United Nations Scientific Committe on the Effects of Atomic Radiations (UNSCEAR). Sources, Effects and Risks of Ionizing Radiation. Report of the General Assembly, United Nations, New York, 1982.

[25] The International Commission in Radiological Protection, "Recommendations of the ICRM, Publication 60, Pergamon Publication, Oxford, 1990.

[26] H. El-Gamal, E. Sidique, M. El-Haddad, M. El-Azab Farid, Assessment of natural radioactivity and radiological hazards in granites of Mueilha area (South Eastern Desert, Egypt), Environ. Earth Sci. 77 (19), 691 (2018). DOI: $10.1007 / \mathrm{s} 12665-018-7880-x$.

[27] United Nations Scientific Committe on the Effects of Atomic Radiations (UNSCEAR). Sources, Effects and Risks of Ionizing Radiation. Report of the General Assembly, United Nations, New York, 2008.

[28] M. Papić, M. Vuković, I. Bikit, D. Mrđa, S. Forkapić, K. Bikit, Đ. Nikolić, Multi-criteria analysis of soil radioactivity in Čačak basin, Serbia, Rom. Journ. Phys. 59 (78), 846-861 (2014).

[29] G. Pantelić, V. Vuletić, M. Eremić-Savković, Lj. Javorina, I. Tanasković, Radioecological monitoring in Serbia, Arhiv veterinarske medicine 2 (2), 59-69 (2009).

[30] I. Bikit, J. Slivka, Lj. Conkić, M. Krmar, M. Vesković, N. Zikić-Todorović, E. Varga, S. Curcić, D. Mrdja,
Radioactivity of the soil in Vojvodina (northern province of Serbia and Montenegro), J. Environ. Radioac. 78 (1), 11-19, (2005).

DOI: 10.1016/j.jenvrad.2004.03.034

[31] Lj. Janković Mandić, S. Dragović, Assessment of terrestrial gamma exposure to the population of Belgrade (Serbia), Radiat. Prot. Dosim. 140, 369-377 (2010). DOI: $10.1093 / \mathrm{rpd} / \mathrm{ncq} 135$.

[32] G. Xhixha, M. Baldoncini, G. Bezzon, G. Buso, I. Callegari, T. Colonna, G. Fiorentini, G. Gjeta, M. Goga, E. Guastaldi, F. Hasani, F. Mantovani, L. Mou, C. RossiAlvarez, V. Strati, M. Xhixha-Kaçeli, A. Zanon, Assessment of Naturally Occurring Radioactive Materials (NORMs) in soils from the Kuçova oilfield, Albania. Proceedings of the $7^{\text {th }}$ International Conference on Environmental and Geological Science and Engineering (EG-'14), Salerno, Italy, 2000, pp. 154-160.

[33] D. Cesar, E. Sokolović, J. Kovač, Radioactivity of soil in Croatia. In: Z. Franić, D. Kubelka, (Eds). Proceedings of $2^{\text {nd }}$ Symposium of Croatian Radiation Protection Society, Zagreb, 1994, pp. 107-114.

[34] K. S. Al-Mugren, Assessment of natural radioactivity level and radiation dose rate in some soil samples from historical area, Al-Rakkah, Saudi Arabia, Natural Science, 7, 238-247 (2015). DOI: 10.4236/ns.2015.75027

[35] I. H. Saleh, Radioactivity of ${ }^{238} \mathrm{U},{ }^{232} \mathrm{Th},{ }^{40} \mathrm{~K}$, and ${ }^{137} \mathrm{Cs}$ and assessment of depleted uranium in soil of the Munsadam Peninsula, Sultatane of Oman, Turkish J. Env. Eng. Sci. 36, 236-248 (2012). DOI:10.3906/muh-1110-1

[36] F. Asgharizadeh, M. Ghannadi, A. B. Samani, M. Meftahi, M. Shalibayk, S. A. Sahafipour, E. S. Gooya, Natural radioactivity in surface soil samples from dwelling areas in Tehran city, Iran, Radiat. Prot. Dosim. 156 (3), 376-382 (2013). DOI: 10.1093/rpd/nct067.

[37] S. A. Mujahid, S. Hussain, Measurement of natural radioactivity from soil samples of Sind, Pakistan, Radiat. Prot. Dosim. 145(4), 351-355 (2010). DOI: https://doi.org/10.1093/rpd/ncq423

[38] D. Otwoma, J. P. Patel, S. Bartilol, A. O. Mustapha, Estimation of annual effective dose and radiation hazards due to natural radionuclides in Mount Homa, southwest Kenya, Radiat. Prot. Dosim. 158 (1), 79-86 (2014). DOI: $10.1093 / \mathrm{rpd} / \mathrm{nct} 031$

[39] N. Yildiz, B. Oto, Ş. Turhan, F. A. Uğur,, E. Gören, Radionuclide determination, and radioactivity evaluation of surface soil samples collected along the Erçek Lake basin in eastern Anatolia, Turkey, J. Geochem. Explor. 146, 34-39 (2014). DOI: 10.1016/j.gexplo.2014.07.013

[40] Ö. Kiliç, M. Belivermiş, S. Topçuoğlu, Y. Çotuk, M. Coşkun, A. Çayir, R. Küçer, Radioactivity concentrations and dose assessment in surface soil samples from east and south of Marmara Region, Turkey, Radiat. Prot. Dosim. 128 (3), 324-330 (2007).

DOI: https://doi.org/10.1093/rpd/ncm400

[41] M. A. M. Uosif, A. M. A. Mostafa, R. Elsaman, M. ElSayed, Natural radioactivity levels and radiological hazards indices of chemical fertilizers commonly used in Upper Egypt, Journal of Radiation Research and Applied Sciences, 7, 430-437 (2014). http://dx.doi.org/10.1016/j.jrras.2014.07.006 
